\title{
GREEN MARKETING TOWARDS HOTEL SUSTAINABILITY: INSIGHT OF INDIA, OPPOURTUNITIES AND CHALLENGES
}

\author{
Patita Paban Mohanty ${ }^{\mathrm{A}}$ \\ Received: June 9, 2020 | Accepted: September 24, 2020 \\ DOI: 10.5937/ZbDght2002181P
}

\begin{abstract}
Hospitality and tourism of India has emerged as one of the key service sectors leveraging country's economy to a greater extent and have led the way for development. The inclusive development has called for sustainability and concern for environment which are need of this hour. As both these two sectors are more resource intensive industry, hence the concept of sustainability, environment and "green" needs to be deliberated from many points of view. The hospitality and tourism industry has substantially contributed socio-economically, but not so much environmentally. In the present scenario, green is the new buzzword and talk of the town, and the hospitality industry has embraced this phenomenal marketing strategy called 'green marketing' as a responsible step towards to the sustainability. In this paper a sincere attempt has been made to unfold the concept, significance and necessity of green marketing in Indian hospitality and tourism industry, also has tried to explore the issues $\mathcal{E}$ challenges of practices during its successful implementation.
\end{abstract}

Keywords: Green Marketing, Sustainability, Hospitality, Environment, Strategy

\section{INTRODUCTION}

By seeing the development process in the $21^{\text {st }}$ century, it has been quite obvious that hospitality and tourism industries are the world's largest service industries growing and accelerating rapidly and contributing a lion's share to the country's economy. Around the world both hospitality and tourism industry has made a remarkable development socio-economically and culturally. The benefits of these sectors have been consumed by each and every citizens of this universe now and then. Simultaneously benefits of these sectors have left behind many detrimental consequences that have influenced not only socio-economically and culturally but also environmentally. In the age of industrializa-

A School of Hotel Management, Faculty of Hospitality and Tourism Management, Bhubaneswar, Odisha, India. Correspondence: $\underline{\text { richhmohanty@gmail.com }}$ 
tion and globalization, people have consumed much of the derived benefits of hospitality and tourism through various practices and performances, but the reverse effects of it has been realized gradually impacting obnoxious environmental consequences.

The resulting consequences are "wake up call" for the customers to contemplate about the environment not only for today but also for the generation next. To think about the today and to preserve the resources for future have been paved the way for the protection and conservation of environment in a much ethical way.

The increased pollution, the overwhelming global warming, climate change, and deforestation has changed the mindset of people, and triggered to originate a new version of consumer concerning about the betterment of environment. It has also changed their life style, pattern of living and other decision-making process revolving around the environmental concerns. The newer pattern of consumers is slowly demanding the product and services which are very close to the environment and that safeguards the inner interest of the environment. This particular demand has forced and initiated the organisation to introduce the new kind of product and services that are labelled as 'environment friendly' or 'green'. Purchasing and selling of these environmentally product and services are called as green marketing. The modern tourism is much more different from the traditional tourism where earlier there is no development process associated with it; the challenge ahead with the modern tourism to minimize the environmental impacts lead to the green marketing. As the environmental problems are increasing day by day, as well as tourism and hospitality industries are both the resource intensive industry, hence there is a paradigm shift towards the green marketing or sustainable marketing. Indian hospitality sector has started the race of going green almost a decade ago, due to the most prolific global tourism destination and hotels are providing green services consistently to their customers (Sharma et al., 2018). The impact of green marketing has catalysed the Indian hospitality sectors to be certified as 'LEED' or 'Ecotel' certified claiming them as strict followers of green norms and regulations (Verma, Chandra, 2018).

Objectives of the study are:

1. To understand the concept and background of green marketing in the context of hospitality and tourism sector and its application.

2. To identify its importance and the reason for imbibing the green marketing in hospitality and tourism industry.

3. To assess the various opportunities and challenges of green marketing that has led to the sustainable development.

The purpose of this paper is to envisage the significance of green marketing to minimize the impact of detrimental effects occurred by these sectors. The adoption of green marketing strategy will definitely help out to eradicate the various environmental issues from the ground level and highlight the issues and challenges faced by the practices. Moreover, the purpose of this study can create awareness towards the environmental practices and instil the 'sense of environmentalism' among the employees, hotel owners, tourism planners and promoters and consumers.

This particular study signifies the much-needed sustainable development in the present age encompassing the contribution and responsibility of hospitality and tourism 
sectors. Sustainable development is a multidimensional concept need to be realized and implemented from the local level to international level. Tourism and hospitality sector in worldwide has a huge scope where the sustainability can be achieved in a much faster way if properly implemented. As hospitality and tourism industry are both resource intensive and people interactive industry, the environmental development in a sustainable way can be achieved. Achieving sustainable development is a long-term spontaneous process, requires a solid monitoring from each level for its achievement. A wider participation of public and private sectors should be required for its successful implementation. Sustainable development is not an automatic process; rather a holistic approach must be initiated, planned for its better fulfilment. In order to achieve the sustainable development, a multidimensional strategy should be designed in the form of green marketing which is crucial for the current situations.

\section{LITERATURE REVIEW}

In the year 1980 and 1990, the rapid developmental process happened all around the globe due to the globalization, which impacts the ecological balance of the environment, resulting many environmental disasters like Minamata disease, mercury poising in Japan; Bhopal Disaster of India, leak of methyl isocyanate; Dust Bowl in Canada and US; Release of CFCs resulting in ozone depletion etc (Wikipedia, List of environmental disasters).

The Catastrophes forced the environmentalist looking for alternatives, to minimize the negative impacts to the environment. The 'decade of environment' in 1990 conceptualized the theory of green marketing to safeguard the environment. The term coined as "sustainability" by the Brundtland Commission in 1987 has paved the way for green marketing in modern era expressing a pattern of resource use that aims to meet human needs while preserving the environment so that these needs can be met not only in the present, but also for future generations. Gradually the sustainable development closely associated with the green marketing which serves its purposes.

According to (Peattie, Crane, 2005), people became aware of environmental consequences that gave birth to the concept of green marketing in 1980, but prior to the conceive of this concept, the American marketing association (AMA) held the first workshop on ecological marketing in 1975.The proceedings of this workshop resulted in one of the first books on green marketing entitled "ecological marketing" (Henion, Kinnear, 1976). Before highlighting the concept and background of the green marketing, the author has narrated the interrelationship of tourism with the environment. For the sake of pleasure and happiness of people, tourism has influenced directly or indirectly on the environment and ecological system of the fragile nature. Tourism and hospitality have offered the product and services that have been also sourced from the environment. Due to the consumption of various product and services, many obnoxious impacts gradually have depleted the environment. Hence the concept of sustainability has come forward to protect and preserve the environment. When the traditional marketing process only looks for the economic development, the marketers strive to imbibe the innova- 
tive process of green marketing or sustainable marketing for the inclusive development. The early definition which supports its concepts and background presented by Peattie in 1995 as "the holistic management process responsible for identifying, anticipating and satisfying the requirements of customers and society, in a profitable and sustainable way" (cf. Walker, Hanson, 1998). Pride and Ferrell (2006) defined the green marketing as an effort that consists of designing, promoting, pricing, and distributing the products that will not harm to the environment. The most recent definitions by (Chamorro, Banegil, 2006) emphasized the relationship of green marketing for protection natural environment. Another definition by Jain and Kaur (2004) of green marketing as the process of using the resources judiciously and producing such products that are environment friendly i.e., the products that do not cause serious destruction and damage to the environment is called Green Marketing. Likewise, Soonthonsmai (2007) defined green marketing as actions carried out by organisations that are apprehensive about the ecology or green problems by providing the environmentally friendly goods or services to bring satisfaction among customers and the community. Referring to another definition given by Rahman, Reynolds, and Svaren (2011), green marketing means a business that is operated in a way that decreases waste, environmentally friendly, saves energy and mostly encourages environmental health and sustainability of the society.

Hospitality and tourism with its amazing development in recent years, has been contributing to so much effects to the nature and the ecology (Graci, Dodds, 2008; Rodríguez, Cruz, 2007). Both industries are expanding at a breakneck speed and contributing the largest share in various developmental process around the world. The benefit and advantages of both these sectors have been experienced by the customers, simultaneously impacts adversely on environment. Both industries are very close to the consumption of environmental resources, therefore, the development process has gradually depleted the resources. Hospitality and tourism industry are resource intensive industry, so in order for sustainability development, green marketing is crucial.

The hotel and tourism industry has tremendous potential to implement sustainable development strategies that are environmentally friendly in many ways. While many hotels have already begun their efforts in this direction, the reality remains that there are only a few countable companies worldwide that have used this successfully (Singjai et al., 2017). Deraman et al. (2017) claim that the perception of the various stakeholders including shareholders, workers and consumers is one of the reasons why hotels are becoming increasingly sensitive to environmental issues. Hospitality industry needs to be more flexible and environmentally conscious.

The significance of green marketing in tourism and hospitality industry arises as it deploys a huge number of across the globe. The increasingly awareness among the consumers consuming the various products and services directly and indirectly are much more concerned about the environment. They have learned not to hostile towards to the environment leading the use of various environmentally friendly products. As a result, green marketing has emerged as one of the most suitable marketing strategies for sustainable development. In the era of modernization, it has become a new marketing myopia for the marketers to fulfil the needs of consumers. The importance of green marketing has become a much-needed criteria for the modern-day hotelier and tourism 
promoters because to keep intact of nature's resources as far as possible for future consumption. In the arena of hospitality and tourism, the necessity of green marketing is enormous which are stated by various authors time to time like according to green marketing is indented to address environmental issues so customers can consider this information in their purchasing decision. The sole aim of hospitality and tourism industry revolves around people, planet and profit, and green marketing is instrumental for satisfying the needs of the green consumers, protecting and safeguarding the planet, and achieving the profit maximisation for the organisation.

Accommodation sector in hospitality that places a significant burden on resource and hence on the environment. This is because the lodging sectors itself wants many mutual resources to better serve its customers (Kasliwal, Agarwal, 2016). Many of the hotel sector's operations are thus causing environmental degradation and climate change on both a national and global scale. The greenhouse gases emitted into the atmosphere and the emission of carbon monoxide and carbon dioxide and chlorofluorocarbons harm the environment tremendously.

Customers have been gradually shown to be environmentally conscious. This puts even greater pressure on hotels to go green, economically and environmentally healthy. As environmental pressure rises, both government and authority are under pressure to implement environmentally friendly policies (Robin et al., 2017). With rising pressure on both hoteliers and authorities, maintaining eco-friendly policies is becoming more and more relevant for hotel operators. Hotels are now expected to use water and energy responsibly to show environmentally sustainable and responsible actions and handle waste responsibly (Zhang et al., 2017). This environmental issue brings about a drastic change in the attitude of consumers towards environmentally friendly business assets and the buying behaviour (D'Souza, Taghian, 2005). As a result, hotels are increasingly interested in maintaining the harmony between environmental resource use, ethical and societal considerations, and issues of profitability (Chan et al., 2013; Hsieh, 2012).

In particular, hotels can no longer ignore their environmental and social obligations, as they use vast quantities of fuel, electricity, water and other non-renewable resources in different operations while supplying customers with goods and services. Hotels can go green in different ways, such as managing energy and water, recycling activities, reducing resource use, partnering with green vendors and offering green services (Rahman et al., 2018; Chan, Hsu, Okumus, 2016). Awareness of the environmental perceptions, demographics and eco-friendly goals of hotel guests will help hotel managers consider their potential clients when formulating successful marketing strategies (Han et al., 2011; Rahman, Reynolds, 2018). Gupta et al. (2019) claim that the ecologically habits of consumers ultimately affect their environmentally friendly buying behaviours (Chan, Hsu, Okumus, 2016). 


\section{GREEN CONSUMER \& THEIR PRODUCTS}

The currentissueslikeglobalwarming, ozone depletion, green house effect, deforstation etc have turned the present consumer to green consumers to adopt the use of enviornmentally friendly products. As stated by French and Rogers (2010), some people have adopted more envionmentally friendly lifestyles, which has led to new purchasing habits. Similarlly Manaktola and Juhari (2007) stated that some prefer to purchase products that have minimal impacts on enviornment and work with firms that use enviornmental practices. These new type of customers are called as 'green consumers', 'enviornmnetaly friendly customers' (Manaktola, Juhari, 2007; French, Rogers, 2010). In the current scenario this particular segment of consumers are devlopping raipdly due to the responsible practices known as green practices. In the United States of America (USA), this segment consists of 19 percent of adult, or 41 million people (Kotler, 2011) and is expected to grow in future. This accounts for an estimated USD 209 billion market in the US alone (Kotler, 2011). This new trend of marketing segmnets has slowly grabbed the hotel and tourism sectors. Costumers having inclination towards to the green initiatives or concerns of enviornmental practices are choosing green hotel over the normal traditional hotel,giving less priority to the personalised service and quality foods.

Those products which are manufactured through a series of green technology and cause no harm to the environment are called green products. The implementation of green technology to the existing manufacturing technology and its promotion is crucial for wide use of green marketing and sustainable development. The green products can be defined by the following features.

According to Jones et al. (2014), green products are viewed as important marketing tool, with many hoteliers competing to provide green products that attract attention from customers. Green products and services are characterized by their ability to minimize environmental impacts or at least have less detrimental impacts on the environment than other similar products and services:

- Originally grown products

- Recyclable, reusable and biodegradable products

- Products containing and manufacturing from natural ingredients

- Products involving recycled contents, non-toxic chemical

- Products contents under approved chemical

- Products that do not harm or pollute the environment

- Products that will not be tested on animals

- Products that have eco-friendly packaging i.e., reusable, refillable containers etc. (iSustainableearth.com, 2014)

Green Products comes in the category of those products which are naturally produce, non-toxic, pollution free, packed with natural and suitable components and having minimal impact on environment and human beings (Siddique, Hossain, 2018). Environmental issues have always been a challenge since the creation of the term environmental sustainability which has increased the sensitivity of consumers towards purchasing greener products (Kumar et al., 2020). Green marketing is a phenomenon which 
has developed particular importance in the modern market. This concept has enabled re-marketing and packaging of existing products (Bhattacharjee, Mukherjee, 2016). It focuses on market eco-friendly products to satisfy the needs and wants of customers (Pradeep, Akhil, 2017). Green marketing in a broader sense is corporate social responsibility because it helps businesses to become socially responsible as well (Kotni, 2020).

Chockalingam (2017) affirms that green marketing started with modification to communication process alone, moved to modification in production process, then to differentiating factor for competitive advantage and evolving every day. Singh and Mehra (2020) state that consumers are more concerned towards environment and health issues as they are more focused on green marketing and green products purchasing. Green products purchasing are expanding among consumers and societies.

In the context of green marketing strategy, one of the effective promotional tool is the green promotion. According to the European Commision (n.d), an effective green promotion includes raising awareness about what companies are doing, providing information regarding a company's values, informing people about the products or services they bring to the market, and reaching the target audience. Numerous ways of conveying green parctices to the costumers like product labels or eco lables, packaging, publicity through trade journals and newsletters, flyers, leaflets and social media. Eco lables and social media are the two strongest promotion channel for the green marketing initiatives in tourism and hospitality sectors. Eco lables are defined as the assurance or the promises of quality of green practices by the hospitality industries. A tourism eco label is the quality certification that determines the minimization of enviornmental detrimnetal impacts and enhances the quality standard of the enviornment. Various examples of eco label pervailling in the hospitality sectors are ISO 14001 certification for enviornemntal managemnet system, green globe 21 for enviornemntal standard in lodging sectors, Accor planet 21 an environemntal initiative by the Accor hospitality group to change the production and consumption pattern, earth check assessment for Asia Pacific Hotels.

Another channel for green promotion is the use of social media and internet technology which have become the most sought after green marketing strategy for the today's hospitality marketeers. Leading international htel groups like Accor, Starwood, and Marriot, Hyaat, have incorporated the enviornmental managemnet system in their business portal clearly stating the hotel's responsibility towards to the energy and water saving, climate change and green house gas effects, waste managemnet and recyclcing.

\section{RESEARCH METHODOLOGY}

The qualitative study of this present paper has taken the advantage of obtaining the various relevant data and information from the secondary sources, by considering research papers from different national and international journals, research articles, conference proceeding papers, periodicals, trade journals, magazines etc. 


\section{INSIGHT FROM INDIAN HOSPITALITY INDUSTRY}

The green initiatives and practices in Indian hospitality industry come into notice a decade ago, and not many hotels do not believe in this emerging concept. The certification like 'Ecotel', 'LEED' by few of the reputed hotel brands creating the ripple for imbibing this tagline.

In Indian scenario, hotels having 'Ecotel' and 'LEED' certification, proves that hotel establishment are strictly following the energy and power saving norms (Verma, Chandra, 2018). Green marketing enters into the Indian hospitality sectors, by seeing the different norms and benefits from the European counterpart. Initially, it was the various strict measure followed by hotel staffs and management like energy and water conservation in order to maintain the cost control. But in the present situation, hotels in India are spending a lot of money and energy on green marketing for its customers and provide them services accordingly (Kasliwal, Agarwal, 2016). Eco Hotels (Ecotels) is a rating scheme supported by International Hospitality Valuation Services (HVS). This framework is focused on five key criteria: environmental responsibility, solid waste management, energy efficiency, water conservation and the participation of employees/community. In India Eco-hotels like Orchid, Rodas, Raintree etc. believing and practicing green marketing.

ITC (Indian Tobacco Company) is one of the world's leading hospitality chain operators famous for its responsible luxury. In order to help environmental causes in the place where it runs its hotels, it has launched the initiative "WelcomEnviron." The program is based on environmentally sustainable policies focused on the recycling, reuse, and reduction concept. The hotel promotes understanding of environmentally friendly practices and increases awareness among employees towards environment and energy conservation and using eco-friendly material and technology (Lakshman, Manjunath, 2015). The Orchid hotel located in Mumbai is the first Ecotel. Thanks to its numerous environmentally friendly programs such as effective solid waste management systems, energy efficiency activities and its dedication to preserving environment, the hotel has been able to receive this award.

Taj Hotels, Resorts and Palaces are another world-renowned hotel known for its heritage and culture. The Taj Group has launched its environmentally sustainable project called the EARTH which is a program for environmental awareness and regeneration. The EARTH programme started as a deliberate attempt to conserve resources and build environmentally friendly sustainable business plans and was formal now. The Fern Hotels and Resorts chain is another example of environmentally sustainable and eco-sensitive hotels adopts the various innovative eco-friendly activities are the use of Ayurvedic soaps and toiletries, environmentally friendly pots, water-saving taps and flushes, the use of paper and cloth bags instead of plastics etc (Kasliwal, Agarwal, 2016). 


\section{OPPORTUNITIES AND CHALLENGES FOR GREEN MARKETING PRACTICES}

There are opportunities to be achieved by increasing awareness among consumers regarding issue of being green (Ambec, Lanoie, 2007; Ottman, 1992). These are the opportunities for both cost reduction and increase in profit (Ambec, Lanoie, 2007). Adopting green marketing practices can be a source of differentiation strategy in the market environment (Ambec, Lanoie, 2008; Ottman, 1992) and the opportunity to access to new markets will be achieved. The opportunity will enhance the corporate brand image, attract the loyal customers. The paradigm shift towards green initiatives will act as an effective tool for the competitive advantage for the organisation. It will also strengthen the company's mission statement by stating the green initiatives as their main theme of corporate social responsibility. Although the awareness of buying green products among the consumers are growing still the challenges for green marketing practices are very complex by nature. The challenges are like obstacles to actually realize and implement the green concepts successfully. As green marketing has been imbibed by the many organisations, but its actual operation is hindered by the consumers, because they are reluctant to pay more for the green products and services. Individually few segments of customers are concerned about the green marketing, but when they realize there is no personal gain, they stay away from purchasing the same. It has been reported that customers show positive intention to visit hotels that adopt green practices than preferring hotels that do not employ them (Ham, Choi, 2012).

According to Mensah (2004), a study done by the International Hotels Environment Initiative (IHEI) and Accor has indicated that $90 \%$ of tourists like to stay in hotels which give attention to the environment. However, when the customers find the green claims are fake or forged, the trust towards the organisation get affected (Bhaskaran et al., 2006). These types of claims are called "green washing" (Sinnappan, Rahman, 2011). Green marketing has been successfully implemented, but some of the factors which influences and hinders the consumer's buying decision for green product. The perception for them is that there are no products such as green products, rather they claimed it as the marketing myopia to allure the customers for profit maximisation.

Some of the other challenges in front of the green marketing make it tougher to be approved and accepted for the public. So, in this case standardization is required and mandatory for authentication of the green product. Also, certification is necessary to claim the product as green product and regulatory body and quality control board should be formed to overcome the various challenges involved with this. Though green marketing is the new buzzword in the Indian consumer market, and awareness among the consumer are in the right track, still the dimension of green marketing is relatively a new concept for the mass. The green movements and thorough knowledge about the environment should reach to every people of the society which will facilitate the green marketing process. To make the green marketing successful, the marketers, hoteliers and tourism stakeholders need to have perseverance and patience, because green marketing is a new endeavour and it requires a long term strategically planning to be successful. 


\section{GREEN MARKETING KNOW-HOWS}

Knowning the customers effectively: The first step towards the implemntation of green marekting should be a through knowldge of consumer background. The marketers should have a good feasibilty study about the intrest shown by the target customers, and in the same time consumers are aware of and cncerned about the product that they are going to be consumed.

Educating customers: Educating the customers about the consequences of enviornment and benefits of protecing the enviornment and conserving its resources are the major consiederation for the green marketing process.

Genuine and transparency strategy: The marketers and the marketing process should be genuine and transparent to prove their enviornmnetal credentials to the consumers. It means that product should delivered what it promised to be delivered. There should be no deviation from the quality as well as standard. A minimal deviation will lead to the failure of green marketing initiatives and will loose the conumer's confidence.

Assurance to the buyer: The green marketing campaign should create the confidence and belive in the mind's of the buyer by giving the quality assurance regarding the products.

Price sensitivity: As envioenmentally friendly products and its ingredients are expensive, the green marketing process requires a sensible pricing to afford all segments of the consumers in the target groups.

Providing consumers a space to particpate: In order to personalize the green marketing process, the consumers should given oppourtunity to particpate the green managament action plan.It will ease the marketing process as well as benefits the larger sections of the society.

\section{POLICY IMPLICATION}

The most important parameters to be considered for promotion of green maketing or to encourgae the usages of green products, is to educate and create the awareness among the public mass through the help of media, newspaper, seminar and confernces. It will familarize them the benefits of preservation and conservation of natural enviornment. Tourism promoters and hospitality policy makers should be aware of the benefits and advantages of green marketing, so that they will propagate this concept to the young generation. Apart from this, the government and other higher authority should play an pivotal role by spreading the message of green marketing and its benefits which will help the consumer to choose the green product in an effective way. For instance green marketing advertsiement and larger publicity of benefits of green products should reach to the public in order to make them habituated about this. The tourism and hospitality marketers should also take initiative for popularization of green marketing by formulating and designing a rigorous marketing strategy focussing on green marketing and succesful implementation of it. In addition to this public and private sectors should come forward and should shared a common goal for sustainable development and implementation of green marketing. 


\section{CONCLUSION}

The environment and the society we live is under the impact of globalization, modernisation in a rapidly manner. Though in one way there is a socio economic development of the society showing a positive growth sign all around, but in another way thers is a constant strain on the enviornemnt creating multitude of problems that is hindering the sustaianble development. As all other developnet is desirable, but to keep this enviornment alive for future generation to come, sustainable develpment is utmost essential for all levels. The hospitality and tourism indsutry are very much associated with the environemnt and environmental resources to keep their business ongoing for the betterment of tourist and costumers. So, to achieve the sustainability development, green marketing is the alternative panacea for it. And it is the ideal time for the discerning consumers, marketers, and other tourism and hospitality policy makers to join in the bandwagon of green marketing campaign for making the successful implementation of it.

\section{DIRECTION FOR FUTURE RESEARCH}

As the green marketing is an emerging concept gradually engulfing the minds of Indian consumers, particularly in hospitality and tourism sectors, still there have an immense scope for further research, as other sectors are slowly coming on the track of green marketing and consumers are much more aware of this green product and are showing a positive attitude towards it. As tourism of India has a stupendous growth in the recent past leveraging the growth of Indian hospitality and allied sectors in other small cities and remote areas. Hence the research should be extended to the consumers of rural areas to know their perceptions and attitude towards the green marketing. Also, there is a scope for research in unexplored tourism destination regarding the introduction of green marketing which will reap a positive result for the tourism professionals and the tourists. Research can be done for the promotion of green tourism which will add on extra feather to the cap of green marketing. Research pertaining to the unorganised sectors of the hospitality and tourism in terms of green marketing can help the industry to get an extra edge over the other sectors.

\section{REFERENCES}

AMA (American Marketing Association). (2007). What are the definitions of marketing and marketing research? http://www.marketingpower.com/content4620.php

Ambec, S., Lanoie, P. (2007). When and why does it pay to be green? (No. 2007s-20). CIRANO.

Bhaskaran, S., Polonsky, M., Cary, J., Fernandez, S. (2006). Environmentally sustainable food production and marketing: opportunity or hype? British Food Journal, 108, 8, 677-690. http://dx.doi.org/10.1108/00070700610682355 
Bhattacharjee, S., Mukherjee, S. (2016). A Descriptive Study on Green Marketing Trends in India. Retrieved from https://papers.ssrn.com/sol3/papers.cfm?abstract id $=2794819$

Chockalingam, S. N. (2017, February 03). A Study on Green Marketing Concept-Emergence to Contemporary Transition for Moderating Climate Change and Environmental Pollution. Retrieved from https://papers.ssrn.com/sol3/papers.cfm?abstract id $=2895584$

Chamorro, A., \& Bañegil, T. M. (2006). Green marketing philosophy: a study of Spanish firms with ecolabels. Corporate Social Responsibility and Environmental Management, 13, 1, 11-24. http://dx.doi.org/10.1002/csr.83

European Commission (n.d). A guide to communicating about CRS. Retrieved from http://ec.europa.eu/enterprise/policies/sustainable.

French, S. Rogders, G. (2010). Understanding the LOHAS Consumer: Lifestyle of health and sustainability (LOHAS). Retrieved from http://www.lohas.com/lohas-consumer

Graci, S., Dodds, R. (2008). Why go green? The business case for environmental commitment in the Canadian hotel industry. Anatolia, 19, 2, 251-270. http://dx.doi.org/1 0.1080/13032917.2008.9687072

Gupta, A., Dash, S., Mishra, A. (2019). All that glitters is not green: Creating trustworthy eco-friendly services at green hotels. Tourism Management, 70, 155-169.

Ham, S., Choi, Y. K. (2012). Effect of cause-related marketing for green practices in the hotel industry. Journal of Global Scholars of Marketing Science, 22, 3, 249-259. http:// dx.doi.org/10.1080/21639159.2012.696338

Han, H., Hsu, L.J., Lee, J.S., Sheu, C. (2011). Are lodging customers ready to go green? An examination of attitudes, demographics, and eco-friendly intentions. International Journal of Hospitality Management, 30, 345-355.

Henion, K., Kinnear, T. (1975). Ecological marketing. American Marketing Association.

iSustainableEarth.com (2014). Green Products. Retrieved from http://www.isustainableearth.com/green-products/what-is-a-green-product

Jain, S. K., Kaur, G. (2004). Green Marketing: An Attitudinal and Behavioural Analysis of Indian Consumers. Global Business Review, 5, 2, 187-205

Jones, P., Hillier, D., Comfort, D. (2014). Sustainability in the global hotel Industry. International Journal of Contemporary Hospitality Management, 26, 1, 5-17.

Kotler, P. (2011). Reinventing marketing to manage the environmental imperatives. Journal of Marketing Management, 75, 4, 132-135.

Kumar Phookan, N., Sarmah, B., Sarika Devi, T. (2020). Exploring determinants of Green Marketing Practices in Food Service Industry to Attain Environmental Sustainability: A Conceptual Analysis. Retrieved from https://papers.ssrn.com/sol3/papers.cfm?abstract id $=3517420$

Kotni, V. P. (2020). Problems \& Prospects of Green Marketing. Retrieved from https:// papers.ssrn.com/sol3/papers.cfm?abstract id $=3627008$

Kasliwal, N., Agarwal, S. (2016). Green Marketing Initiatives and Sustainable Issues in Hotel Industry. In: Handbook of Research on Promotional Strategies and Consumer Influence in the Service Sector (pp. 197-214). IGI Global. 
Lakshman, R., Manjunath, R. (2015). Green Management and Environmental Sustainability: A Case Study of ITC Hotel. Adarsh Journal of Management Research, 8, 1, 6469.

Manaktola, K.., Jauhari, V. (2007). Exploring consumer attitude and behaviour towards green practices in the lodging industry in India. International Journal of Contemporary Hospitality Management, 19, 5, 364 - 377.

Mensah, I. (2004). Environmental management practices in US Hotels. Retrieved from http://www.hotelonline.com/News/PR20042nd/May04EnvironmentalPractices. html.

Millar, M., Baloglu, S. (2011). Hotel Guests' Preferences for Green Guest Room Attributes. Cornell Hospitality Quarterly, 52, 3, 302-311. http://dx.doi. org/10.1177/1938965511409031

Pradeep M. D., Akhil, A. (2017). Green Marketing to Meet Consumer Demands and Sustainable Development-Challenges and Opportunities. Retrieved from https://papers.ssrn.com/sol3/papers.cfm?abstract id=2980024

Ottman, J. A. (1992). Green Marketing - Challenges \& Opportunities for the New Marketing Age. Chicago: NTC Business Books.

Peattie, K., Charter, M. (1994). Green Marketing. The Marketing book, 726-755.

Peattie, K. (1995). Promotional competitions: A winning tool for tourism marketing. Journal of Tourism Management, 17, 6, 432-442.

Peattie, K. (2001). Towards Sustainability: The Third Age of Green Marketing. Marketing Review, 2, 2, 129.

Peattie, K., Crane, A. (2005). Green marketing: legend, myth, farce or prophesy? Qualitative Market Research: An International Journal, 8, 4, 357-370. http://dx.doi. org/10.1108/13522750510619733

Rahman, I., Reynolds, D., Svaren, S. (2011). How "green" are North American hotels? An exploration of low-cost adoption practices. International Journal of Hospitality Management, 31, 3, 720-727. http://dx.doi.org/10.1016/j.ijhm.2011.09.008

Rahman, I., Reynolds, D. (2018). The influence of values and attitudes on green consumer behavior: a conceptual model of green hotel patronage. International Journal of Hospitality and Tourism, 2, 1-28.

Rodríguez, F. J. G., Cruz, Y. (2007). Relation between social-environmental responsibility and performance in hotel firms. International Journal of Hospitality Management, 26, 4, 824-839. http://dx.doi.org/10.1016/j.ijhm.2006.08.003

Sinnappan, P., Rahman, A. A. (2011). Antecedents of Green Purchasing Behaviour among Malaysian Consumers. International Business Management, 5, 3, 129-139. http://dx.doi.org/10.3923/ibm.2011.129.139

Singh, B. P., Mehra, R. (2020). A Study on Consumer Awareness Towards Green Marketing with Special Reference to Indore Region. Retrieved from https://papers.ssrn.com/ sol3/papers.cfm?abstract id=3523549

Soonthonsmai, V. (2007). Environmental or green marketing as global competitive edge: Concept, synthesis, and implication. In: EABR (Business) and ETLC (Teaching) Conference Proceeding, Venice, Italy. 
Siddique, M. Z. R., Hossain, A (2018). Sources of consumers awareness toward green products and its impact on purchasing decision in Bangladesh. Journal of Sustainable Development, 11, 3, 9-22. https://doi.org/10.5539/jsd.v11n3p9

Verma, V. K., Chandra, B. (2018). Intention to implement green hotel practices: evidence from Indian hotel industry. International Journal of Management Practice, 11, 1, 2441.

Wikipedia, List of Environmental Disasters, Retrieved from http:/en.wikipedia.org/ wiki/List of environmental disasters

\section{CONFLICTS OF INTEREST}

The author declared no potential conflicts of interest with respect to the research, authorship, and/or publication of this article.

(C) 2020 by the author. This article is an open access article distributed under the terms and conditions of the Creative Commons Attribution (CC BY) license (http://creativecommons.org/licenses/by/4.0/). 